Department of Agricultural Chemistry, School of Agriculture, University College of North Wales; Mr. Brian T. Little (University College, Dublin), at the Department of Industrial Microbiology, University College, Dublin; Mr. Cornelius Long (University College, Dublin), at the Department of Experimental Physics, University College, Dublin; Mr. Vivian Timon (University College, Dublin), at the School of Agriculture, Newcastle upon Tyne (University of Durham).

\section{Ciba Fellowships}

Several Ciba Fellowships will be awarded for tenure during the academic year 1960-61 at Continental universities or institutions for research in chemistry, physics or some other allied scientific subject. They will be awarded to graduates of universities of the British Isles. The basic award for Fellows who wish to continue postdoctorate studies

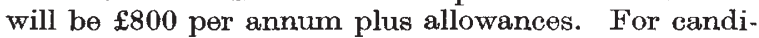
dates who have obtained a first degree in science and wish to undergo training in research, the basic award will be $£ 500$ per annum plus allowances. The total value of each fellowship will be determined by the advisory panel, and will be sufficient to cover the Fellow's living and other expenses (including fees and cost of travel) during the tenure of his fellowship, which will be for one year, renewable for a further one or two years. Six Fellowships were awarded last year for tenure in 1959-60, and Ciba Fellows are at present working at Zurich, Göttingen, Louvain, Heidelberg and Copenhagen. Applications should be made in duplicate on forms obtainable from the Secretary to the Ciba Fellowship Trust, Ciba (A.R.L.), Ltd,, Duxford, Cambridge. The closing date for such applications is January 31, 1960.

\section{University News :}

Belfast

THE appointment of Dr. F. J. Wallace (Birmingham) to senior lecturer in mechanical engineering is announced, also L. J. Clein (Maudsley Hospital, London) to be lecturer in mental health.

Bristol

THE following appointments are announced: Dr. J. W. Barton (Bristol), lecturer in organic chemistry ; Dr. D. L. Dineley (Birmingham), lecturer in geology; Dr. K. R. Gough (Bristol), research fellow in medicine; Dr. S. Griew (London), lecturer in psychology ; Dr. M. A. Hollingsworth (London), lecturer in mechanical engineering; B. S. Smith (Manchester), lecturer in civil engineering; D. J. Storey (Cambridge), lecturer in electrical engineering; Dr. C. J. Waddington (Bristol), lecturer in physics.

The Department of Scientific and Industrial Reseach has made grants as follow : to the Department of Physics, $£ 16,680$ for research under the direction of Prof. C. F. Powell for experiments in cosmic radiation with balloons, photon-induced cascades at different altitudes, and time variations in the primary cosmic radiation over Great Britain; $£ 35,084$ to the Department of Psychology, for research into the complexity of industrial tasks; to the Department of Geology, $\$ 5,000$ for investigations of feldspars in the Connemara granite series and preferred orientation in rock-forming minerals; and $\mathbf{£ , 5 5 0}$ for investigations of the submarine geology of the continental shelf of the Western Approaches of the English Channel by Prof. F. Whittard; $£ 3,850$ to the Department of Physical and Inorganic Chemistry for equipment; and $£ 2,880$ to the Department of
Zoology for investigations of the physiological basis of behaviour in protozoa. The National Coal Board has made a grant of $£ 1,150$ to the Department of Physical and Inorganic Chemistry for a study of carbon surfaces and surface complexes by infra-red spectroscopy, and $£ 1,100$ for a study of reactivity of carbon surfaces with oxygen. A grant not exceeding $£ 1,150$ has been made by the Ministry of Supply to the Department of Electrical Engineering for research on noise generation in inductors with ferromagnetic cores (continuation of grant).

London

Dr. P. B. D. DE LA Mare (New Zealand), reader in chemistry at University College, has been appointed to the University chair of chemistry tenable at Bedford College from October 1, 1960. The title of professor of experimental physics in the University of London has been conferred on Dr. F. C. Champion (Cambridge), in respect of his post at King's College. The following readerships are announced: Dr. D. R. Arthur (Wales), in zoology, in respect of his post at King's College ; Dr. J. B. Hasted (Oxford), in physics, in respect of his post at University College.

\section{Announcements}

THE Physical Society has announced a conference on "Electron-Phonon Interaction in Solids", to be held in the Townsend Lecture Theatre, Clarendon Laboratory, Oxford, during December 17-18. Further information can be obtained from Miss E. Miles, Physical Society, 1 Lowther Gardens, Prince Consort Road, London, S.W.7.

The Royal Institution has announced the one hundred and thirtieth course of six Christmas lectures adapted to a juvenile auditory. The lectures, entitled "The Release and Use of Atomic Energy", will be given by Dr. T. E. Allibone on December 29 and 31, 1959, and January 2, 5, 7 and 9, 1960. Further information can be obtained from the Royal Institution, 21 Albemarle Street, London, W.I.

The Home Universities Conference, 1959, will be held in the Senate House of the University of London during December 11 and 12. The topics for discussion are: "University Co-operation in the Commonwealth"; "University Libraries"; and "Administrative Problems in Expanding Universities".

THE Institution of Mechanical Engineers is arranging an informal diseussion on the Computer in Production, to be held on March 21 and 22. The purpose of the meeting is twofold : to introduce chartered mechanical engineers and managers to the latest techniques involving the application of computers in production; and to provide a forum for managers, engineers and users to present their views to manufacturers of computers. Visits to computer centres and to installations where computers are being used on production problems will be arranged. Further particulars can be obtained from the Secretary, Institution of Mechanical Engineers, I Birdcage Walk, London, S.W.1.

Errata. Prof. Daniel I. Arnon has pointed out the following mistakes which were overlooked in proof-reading in his article entitled "Conversion of Light into Chemical Energy in Photosynthesis" in Nature of July 4, p. $10:$ p. 11, col, 2, last word in the first paragraph should read "phosphoglycerate"; p. 11, equation 3, right-hand side, should be " 4 $\mathrm{Fe}^{2+} \ldots "$; p. 17, col. 1, equation 7, left-hand side, should be ". . . 2(Chlp) $)^{+}$...". 